\title{
Violencia y cruce de propagandas: la metáfora de la víctima. Las fotografías de la Rebelión Cristera ${ }^{1}$
}

\author{
Indarkeria eta propaganden gurutzatzea: biktimaren metafora. \\ Kristeroen Matxinadako argazkiak \\ Violence and Propaganda: The Victim Metaphor. \\ The Photographs of the Cristero Rebellion
}

\author{
Marisol Romo Mellid` \\ Universidad de Valladolid en Segovia
}

\begin{abstract}
RESUMEN: Las fotografias de la Rebelión Cristera en México fueron una parte fundamental del conflicto, entre otras razones, porque los dos bandos utilizaron las mismas imágenes como propaganda. Así, los cristeros las instrumentalizaron para denunciar la violencia que se ejercía contra ellos y consolidar la imagen del mártir. Mientras que el gobierno de Calles realizó y publicó fotografias de las ejecuciones de cristeros, para imponer el exterminio como castigo a los alzados. El cruce de propagandas provocó que las víctimas de ambos bandos se configuraran, desde las fotografias, como metáforas de su propia aniquilación y expresión de la perversidad del otro.
\end{abstract}

PALABRAS CLAVE: Rebelión Cristera; fotografia y propaganda; México; fotografia y guerra; violencia.

ABSTRACT: The photographs of the Cristera Rebellion in Mexico were one more part of the conflict because fighters of the war used the same propaganda images. Thus, the Cristeros used the images to denounce the violence that was committed against them, and also to create the image of the Cristero martyr. The government, for its part, made and published photographs of the cristeros executions, to punish the rebels. The propaganda produced the victims disappear and the photographs only showed the metaphor of their own annihilation, at the same time that they expressed the perversity of the other.

KEYWORDS: Cristero Rebellion; photography and propaganda; Mexico; photography and war; violence.

\footnotetext{
1 Investigación financiada por el Dep. de Educación, Universidades e Investigación del Gobierno Vasco, dentro del Programa de Perfeccionamiento de Doctores en el Extranjero en Ciudad de México.

* Correspondencia a / Corresponding author: Marisol Romo Mellid. Fac. CC. Sociales, Jurídicas y de la Comunicación, Universidad de Valladolid en Segovia, Plaza de la Universidad, 1 (40005 Segovia) - sol.romo1@gmail.com - https://orcid.org/0000-0003-4142-7177

Cómo citar / How to cite: Romo Mellid, Marisol (2019). "Violencia y cruce de propagandas: la metáfora de la víctima. Las fotografías de la Rebelión Cristera», Zer, 25(47), 119-146. (https://doi.org/10.1387/zer.21003).

Recibido: 10 julio, 2019; aceptado: 26 septiembre, 2019.

ISSN 1137-1102 - elSSN 1989-631X / (C) 2019 UPV/EHU

(c) (7) Esta obra está bajo una licencia

Creative Commons Atribución 4.0 Internacional
} 


\section{Introducción}

Ahorcados de los cables telegráficos de las vías del tren y de árboles, instantáneas de fusilamientos, agrupamientos de cadáveres de cristeros caídos en combate o ejecutados, militares exhibiendo orgullosos a los cabecillas cristeros —en ocasiones sujetándoles los brazos para mantenerlos incorporados ante las cámaras y poder así mostrar mejor los cuerpos muertos-, retratos post mortem en los lechos mortuorios y primeros planos de los tiros de gracia y de los rostros de los fusilados. Ésas son algunas de las fotografias más impactantes que han quedado de la Rebelión Cristera en los archivos y las hemerotecas de México. Todos esos muertos son del bando cristero y, tanto los cristeros como el gobierno, utilizaron las citadas fotografias en su propaganda hasta convertirlas en parte importante del enfrentamiento.

La Rebelión Cristera o Cristiada ${ }^{2}$, ocurrida entre 1926-1929 en México, enfrentó en una guerra al Gobierno de Plutarco Elías Calles con grupos católicos. Los bandos que se enfrentaron fueron el gobierno y ejército federal, por un lado, y las bases cristeras (campesinos, indígenas y curas) e intelectuales de la Liga Defensora de la Libertad Religiosa, por otro. Hubo fanatismo en los dos bandos y se han conservado fotografias con altas dosis de violencia ${ }^{3}$, pero prácticamente solo está presente la víctima cristera.

Hoy se sabe que la crueldad fue igual de intensa en ambos bandos y que hubo mucho ensañamiento. Por tanto, se hace necesario analizar los intereses y las estrategias de propaganda que llevaron a cabo tanto el gobierno como los cristeros, que paradójicamente utilizaron las mismas fotografias para imponer sus respectivos mensajes. Las contradicciones del conflicto permitirán, por su parte, entender la importancia que la fotografia tuvo en la Rebelión Cristera; especialmente en un contexto de máxima censura y de oscuridad que perdura hasta la actualidad.

\footnotetext{
2 Por cuestiones estratégicas, todos los dirigentes revolucionarios habían evitado la puesta en práctica de las reformas en materia religiosa de la Constitución de 1917; hasta que el presidente Plutarco Elías Calles tomó la iniciativa y promulgó la Ley Calles, que prohibía la enseñanza religiosa, obligaba a la disolución de órdenes monásticas, exigía la entrega de bienes inmuebles al Estado y también prohibía a los religiosos la intromisión en asuntos políticos. El Episcopado Mexicano, por su parte, decretó suspensión de cultos y el cierre de iglesias y templos el mismo día que entró en vigor la ley; lo que provocó los primeros levantamientos y la guerra.

3 Para la realización de la investigación, se han estudiado tanto las fotografias publicadas como las que están en los archivos de Ciudad de México. En realidad, no hay gran diferencia entre lo que está en los archivos y lo que se publicó. La censura en los archivos, en torno a este tema, es todavía muy fuerte y la mayoría de las fotografias pertenecieron a expedientes. Al final del artículo se indican los archivos y publicaciones que se han tenido en cuenta en esta investigación, como corpus de imágenes a estudio.
} 
El gobierno controló los medios impresos de mayor tirada y realizó y publicó numerosas fotografias de los muertos y ejecutados del bando cristero para desarrollar una estrategia propagandística, con la que se escenificaba el exterminio del otro. Los cristeros, por su parte, difundieron todas las imágenes en las que se mostraba la violencia que se ejercía contra ellos; aunque se beneficiaron de la estrategia propagandística gubernamental que les permitió, paradójicamente, intentar estabilizar y engrandecer la imagen del mártir sin conseguirlo del todo.

Así, las estéticas del martirio y del exterminio trataron de imponerse, mezclarse y anularse en unas fotografias donde la violencia en sus expresiones más radicales ocupa todo el espacio fotográfico. En ese contexto, la imagen de la víctima surge del cruce de ambas estrategias estéticas y propagandísticas para colocarse en un lugar, en el que «la puesta en escena de la memoria, se detiene en favor de un conjunto complejo de metáforas» (Durand, 1990: 106).

\section{Límites estéticos de la representación: enmascarar a la víctima}

Las fotografias con alto contenido de violencia fueron rápidamente asumidas como una parte más de la guerra, poniendo en evidencia en qué medida "ofrecen la oportunidad al espectador de dejarse seducir por lo prohibido y por los tabúes, incluidos los tormentos psicológicos y las muertes macabras» (Taylor, 1998: 14), perfilándose así el problema del posible camino de desintegración de la víctima, en un escenario de radicalidad estética, que va ofreciendo su propia versión de los hechos. Los límites estéticos, en este caso, ayudarán a entender la forma en que se construye la imagen de la víctima, en relación directa con los mecanismos de estetización de la fotografia, desde un contexto de violencia y de discursos propagandísticos extremos. Se trata, en todo caso, de atender y entender la complejidad estético-discursiva de esas imágenes en el proceso de deconstrucción y construcción de la víctima en términos genéricos.

Por tanto, un primer límite estético a considerar, estaría relacionado con la necesidad de dirigir la lectura e interpretación, porque «las fotografias de una atrocidad pueden producir reacciones opuestas. Un llamado a la paz. Un grito de venganza. O simplemente la confundida conciencia (...) de que suceden cosas terribles» (Sontag, 2003: 21). Pero, "la violencia puede exaltar a alguien subyugado y convertirlo en mártir o héroe» (ibídem). De hecho, la exacerbación del mártir fomentó en los cristeros el deseo de alcanzar el martirio, como el camino divino para la salvación, y el empleo de la fotografía cumplió un papel trascendental en el éxito del adoctrinamiento de los cristeros. El paroxismo llegó a tal punto que, incluso en ocasiones, parecía que era "el sacrificio de los cristeros mucho más importante que la muerte de los perseguidores» (Meyer, 1973c: 301). 
Habitualmente el mártir se identifica con la persona «que padece muerte por amor de Jesucristo y en defensa de la religión cristiana» ${ }^{4}$. Sin embargo, el martirio

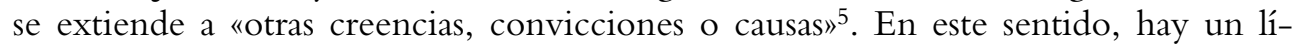
mite estético claro, que tendría que valorarse adecuadamente dada su importancia, y que tiene que ver con el ocultamiento de las víctimas no cristeras, por parte de los dos bandos; como consecuencia de sus estrategias propagandísticas. Los cristeros, por un lado, utilizaron las imágenes de sus muertos para lanzar acusaciones contra el gobierno de Calles; mientras que el ejecutivo quiso mostrar a los cristeros muertos como elemento disuasorio, para intentar frenar cualquier manifestación de rebeldía. De tal forma que, se dio por sentado, que el cristero era el único mártir; especialmente porque era un conflicto aparentemente religioso.

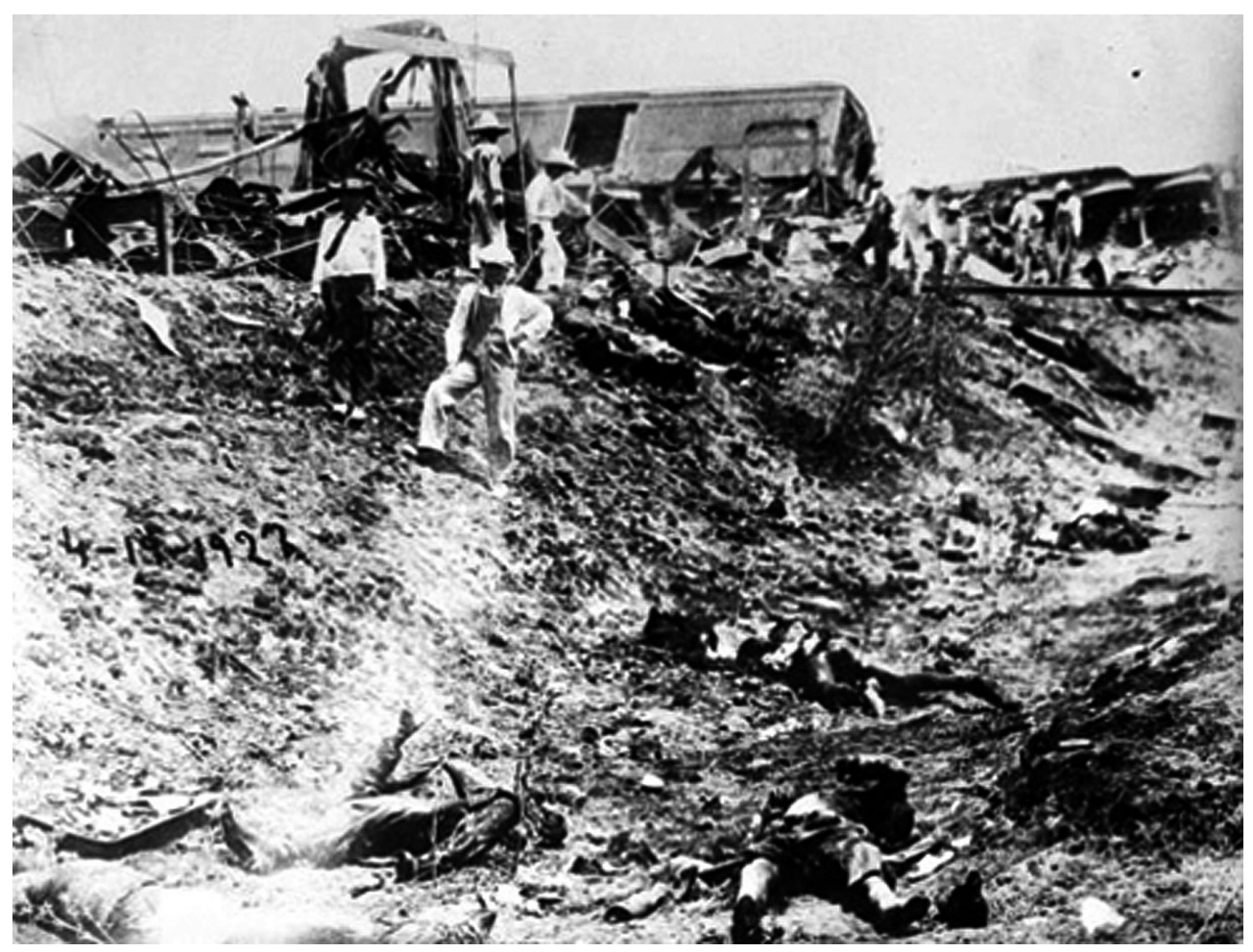

(C) SINAFO-Fototeca Nacional.

Fotografía 1

Tren asaltado e incendiado por cristeros, cerca de la Barca, 1927

${ }^{4}$ Definición de la Real Academia Española de la Lengua.

5 Ibídem. 
El asalto realizado por los cristeros contra los pasajeros del tren rápido que hacía el trayecto de Guadalajara-México, ocurrido en la Barca el 19 de abril de 1927 y donde perdieron la vida alrededor de cincuenta personas, constituye un paradigma modélico de estudio. El periódico Excelsior publicó en portada: «No contentos con haber dejado un sinnúmero de heridos y muertos, arriba de los mismos carros, prendieron fuego al tren sin importarles los lamentos de los que aún quedaban con vida» ${ }^{6}$. Por el contrario, "escritores católicos, han explicado (...) que antes de incendiar el tren, sacaron a todos los heridos, dejando solo a los muertos» (Olivera, 1966: 184). En todo caso, existe un negacionismo implícito hacia la otra víctima, a pesar de lo visible que resulta desde la espeluznante presencia de los cadáveres esparcidos por el suelo en un escenario dantesco; donde el tren encauza el retorno a la realidad de la tragedia. Para los militares, los cristeros tampoco eran víctimas, sino rebeldes, alzados, fanáticos y cabecillas.

La muerte en circunstancias violentas, en el campo de batalla, ante el pelotón de fusilamiento o colgado, entre otras formas, formaba parte del camino obligado a seguir para ser mártir; pero siempre con mucha visibilidad fotográfica e incluso la misma fotografia ya era una parte del camino del martirio. No obstante, en el libro: La vida airada. Imágenes del agrarismo en Guanajuato ${ }^{7}$, se incluyen varias fotografias de agraristas asesinados por cristeros. En la fotografia del velatorio del campesino Diego López de Misión, puede verse al fallecido en primer plano sobre una tabla de madera. El muerto está rodeado de velas. Los acompañantes de Diego López miran directamente al objetivo fotográfico, sin que exista una voluntad clara de exhibir al fallecido como trofeo; pero sí de constatar el hecho mismo y el duelo que conlleva. Sobre todo si se tiene en cuenta que, en ese mismo libro, se publican también imágenes de cabecillas cristeros fusilados y muertos en combate, con una intención mucho más marcada de mostrar el cadáver, reforzada desde el propio pie de foto: «Exhibición de cadáver cristero». En los pies de fotos de los agraristas, por el contrario, se habla siempre de campesino asesinado por cristeros.

El libro incluye, además, una fotografía de nueve campesinos asesinados en el rancho de Dulces Nombres por un grupo de cristeros. Los cadáveres en esta ocasión están colocados en vertical hacia la cámara. De nuevo, un primer plano para los fallecidos y, al fondo, un grupo de personas que hace las veces de cortejo fúnebre; mientras miran directamente al objetivo. Los cadáveres están tapados con una sábana

\footnotetext{
${ }^{6}$ Boletín del Estado Mayor, Periódico Excelsior, 21 de abril de 1927, p. 1.

7 Consúltese: CERVANTES, Beatriz; CRESPO, Ana María; FLORES, Luz María, La vida airada. Imágenes del Agrarismo en Guanajuato, Gobierno del Estado de Guanajuato. Primera edición en la Colección Nuestra Cultura, Guanajuato, 1989. En el libro, se incluye la colección que reunió el líder agrarista Alfredo Guerrero Tarquín, de los acontecimientos que tuvieron lugar en la región noroeste del Estado de Guanajuato de los años 20 a los 40.
} 
blanca, a excepción de la cabeza que es la única parte que puede verse del cuerpo. Y esta fotografía escenifica también el duelo, más que el escarmiento. Pero conviene insistir en que la víctima no cristera fue la más disimulada desde la fotografia, lo que pudo condicionar incluso las diferencias a la hora de enfrentarse con la muerte, la forma de exponer a los muertos y el propio impacto visual resultante, mucho más pronunciado en las que hay cadáveres de cristeros; ya que los aspectos morbosos lejos de aminorarse se refuerzan.

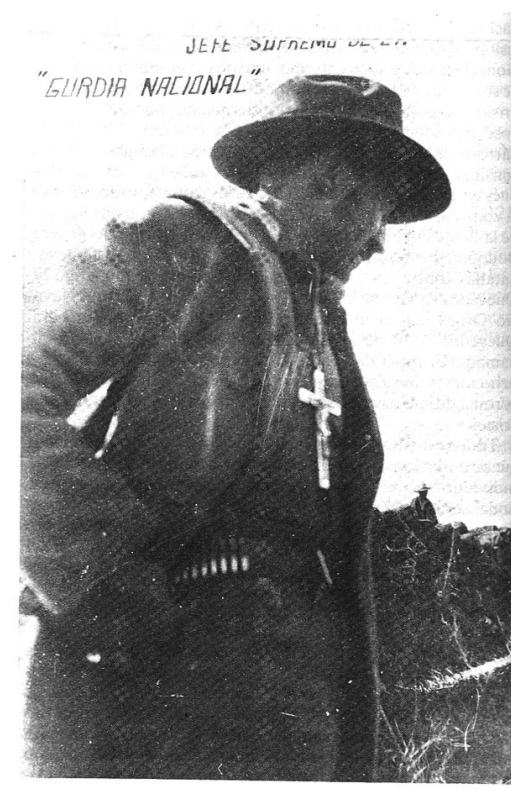
General en jefe de la Guardia Nacional (cristeros). Enriquc Gorostieta

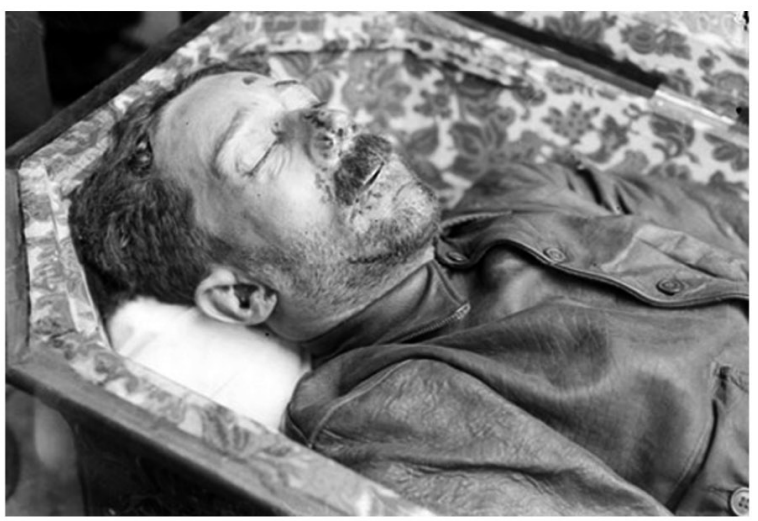

(C) SINAFO-Fototeca Nacional.

\section{Fotografía 2}

Enrique Gorostieta

Se podría decir que el caso del General Enrique Gorostieta evidencia lo que se podría entender como un tercer límite estético de representación, en relación a las dificultades ideológicas a la hora de consolidar al mártir. El Archivo Casasola conserva una fotografia suya, en la que se le puede ver montado a caballo y posando directamente a la cámara, asumiendo a la perfección su papel de general del ejército cristero, que otorga con su pose organización a unos combatientes desorganizados hasta su llegada en julio de 1927; aunque esa fotografía se hizo seis años antes. En otra toma del Archivo Casasola, se le ve en un retrato post mortem en el ataúd con signos visibles de muerte violenta. Su consolidación como mártir era complicada 
porque ponía en evidencia las contradicciones de la Liga ${ }^{8}$ : «He aquí un movimiento que se decía consagrado a defender la religión, pero del cual se conocían los designios políticos, y que no vacilaba en buscarse un jefe militar en las filas de los revolucionarios» (Meyer, 1973a: 201).

Gorostieta encabezó un grupo de campesinos descontento por «la defectuosa o nula aplicación de las cláusulas de la Constitución en materia agraria» (Olivera, 1966: 258-9), por lo que se le unieron "grupos que tradicionalmente habían permanecido al margen de los intereses comunes a los católicos (...) como los agraristas» (ibídem). De tal forma que su imagen está muy marcada por las propias contradicciones del conflicto.

Además, entró en la contienda como mercenario9. Por tanto, Gorostieta no encajaba en la imagen de mártir. Hay otra fotografia de Gorostieta durante la Cristiada, en la que lleva colgado un gran crucifijo, que hace de hipérbole a modo de borrado de un pasado antirreligioso y que explica su conversión al cristianismo; pero su apego a los símbolos cristianos no fue suficiente. Por otro lado, su muerte programada ${ }^{10}$ marcó un punto estético de inflexión hasta llegar al final de la guerra, en base a unos acuerdos entre la Iglesia y el Estado, que él no apoyaba y que conllevaron para los cristeros la renuncia definitiva a la imagen de mártir. Especialmente porque la Iglesia había abandonado a los cristeros a su suerte desde el principio: "Providencialmente hubo cristeros; providencialmente dejó de haberlos»" (Meyer, 1973a: 29). De tal forma que el mártir cristero se movía en los extremos estéticos, éticos y políticos de la afirmación: «Será una lección para el futuro» ${ }^{12}$ (ibídem) y de la negación también en el seno de su propio grupo. Mientras que la víctima no cristera, por su lado, era negada desde su escasa representación e instrumentalización fotográfica.

\footnotetext{
8 La liga agrupaba a diferentes asociaciones, entre las que destacaban: los Caballeros de Colón, Damas Católicas, Congregación Mariana de Jóvenes, Confederación Nacional Católica del Trabajo y la Asociación Católica de Jóvenes Mexicanos (ACJM) presidida por René Capistrán Garza. Según Meyer, la Liga se quejaba de no encontrar ayuda financiera entre los ricos católicos.

9 Según Meyer, Gorostieta se alquiló por 3.000 pesos oro al mes y la Liga suscribió con él, además, un seguro de vida de 20.000 pesos, que llegó a recibir su viuda.

${ }^{10}$ El hecho de que representara un estorbo para que se llevaran a cabo los arreglos y las circunstancias en que fue atacado, hicieron sospechar que se trató de una emboscada.

11 Declaraciones del Cardenal Dávila Garibi, tras valorar el incendio de una hacienda de un rico bienhechor de la Iglesia, llevado a cabo por los cristeros, al negarse su propietario a pagar el impuesto de guerra.

12 Palabras de Monseñor Ruiz y Flores, que parecen centrarse en la imagen que del cristero tendrá las generaciones venideras, siempre y cuando no se escenificara una lucha por el poder.
} 
Existe otro ejemplo, además del de Gorostieta, de las dificultades para consolidarse como mártir. Se trata de José de León Toral, que fue ejecutado por asesinar a Álvaro Obregón el 9 de febrero de 1929. Su estabilización como mártir, solo era factible, si el discurso fanático le permitía la transformación definitiva: de ser un asesino, pasar a ser una víctima. Y para lo cual hay que «aparecer como una víctima de la tiranía, hay que imponer una visión miserabilista de uno mismo» (Bruckner, 1996: 127). Las fotografias del juicio y de la estancia en prisión de Toral sustituyen la violencia por la exposición ante la opinión pública del ocaso del mártir, del «hombre caído en desgracia» (Eliade, 1992: 149), que necesita «agarrarse a una significación transhistórica» (ibídem). El ejemplo de Toral pone en evidencia la intención de identificar los crímenes cometidos por los cristeros con los ideales místicos: «Esos asesinatos ejecutados por individuos que la Iglesia califica de santos, son considerados por los católicos a través de los siglos, como hechos heroicos» (Sodi de Pallares, 1936: 34).

La paranoia de Toral lo fue también en alguna medida de todo el movimiento cristero. Los dibujos que él mismo hizo, sobre las torturas a las que fue sometido en la cárcel, constituyen todo un paradigma del cruce entre la visualidad del martirio, el hecho violento y un arrepentimiento pasional que predicó en sus escritos en prisión. En medio de toda esta estrategia de consolidación de León Toral como mártir, las fotografias ofrecen un aspecto inédito, que tiene que ver con la insistencia de fijar en el espectador al acusado en el juicio, en la prisión y en las protestas de sus seguidores, que parecen anular el relato sangriento del crimen que cometió. Ese mismo relato que le impidió ser mártir.

El discurso estético de la muerte y de lo abyecto, por otro lado, se configurarían como un cuarto límite de representación. En este sentido, hay una dialéctica implícita, de la experiencia traumática de enmascaramiento de la víctima, que se establece entre la poética de la muerte, las ausencias y la brutalidad de las escenas fotografiadas. Toda vez que se ha referido con anterioridad las diferencias, entre ambos bandos, a la hora de exhibir los cadáveres y al propio impacto visual de las fotografias. Así, en los archivos se conservan fotografias sueltas e incluso secuencias completas de fusilamientos de cristeros.

En algunos casos, como en la fotografia del coronel Gabino Flores y su acompañante, se pone en evidencia desde el texto las traiciones a los cristeros tras los acuerdos de paz: «En 1931 fue asesinado a traición, a pesar de las garantías pactadas». Las manos que sujetan las cabezas, la escena abyecta en sí y el pie de foto, escrito por cristeros, tratan de dejar claro quién debe ser exterminado; en ese cruce peligroso de mensajes estéticos y propagandísticos: rebelde-mártir; mortal-divino; víctimaverdugo; vivo-muerto; muerte-resurrección; sadismo-masoquismo entre otros. Son víctimas elevadas a la sofisticación del hiperónimo cristero y, por eso deben ser debidamente proclamadas y certificadas, en el propio escenario radical de desintegración de la víctima: «Coronel Gabino Flores, excelente y honrado oficial». La muerte y el 
relato heroico, asimismo, apelan a la lucha, desde el esplendor del tormento. Ahora bien, el acompañante ni siquiera es nombrado, aunque sí se menciona al enemigo aparente: los agraristas; en este cruce visible de propagandas.

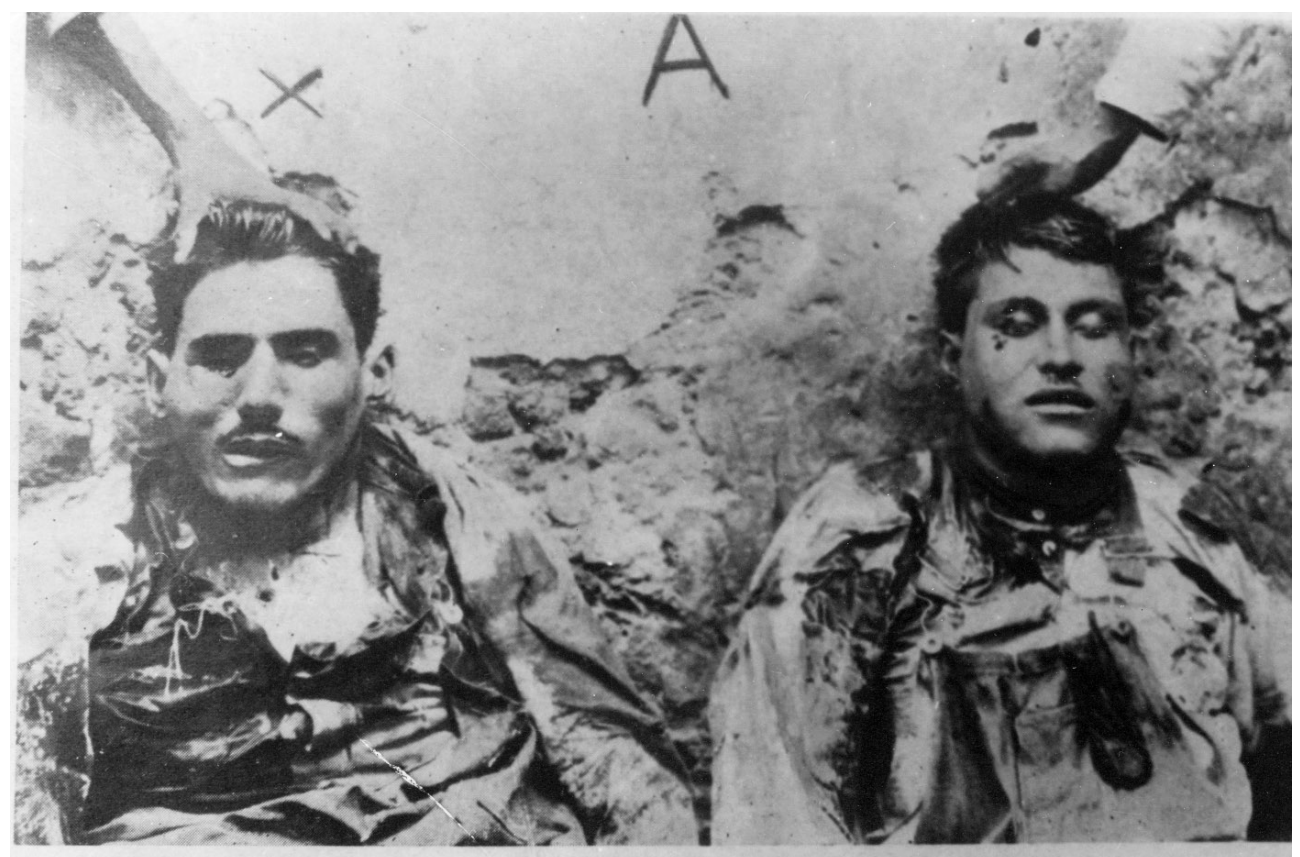

(x) Coronel Gabino Flores, excelente y honrado oficial, defendió Tepatitlán con 350 cristeros contra 6.000 agraristas de Cedillo, logrando rechazarlos. Depuso las armas en julio de 1929. En 1931 fué asesinado a traición, a pesar de las garantías pactadas.

(C) IISUE/AHUNAM / Fondo Aurelio Robles Acevedo.

FOTOGRAFÍA 3

Exhibición de cadáveres cristeros

Por último, el dolor que se presenta como un límite estético comprometido en todas estas fotografias, dado que las propias imágenes del conflicto sirvieron, paradójicamente, a modo de sedante para poder asumir un escenario de consunción del inmolado, en el cual es difícil acceder «al saber proporcionado por las narraciones (...) que es simbólico, emocional y metafórico (...) como un interlocutor con el que poder dialogar» (Marzabal, 2007: 24). Por tanto, la víctima de la Cristiada es una metáfora inaccesible y perdida en medio de un relato trágico, desfigurado y sangriento.

El archivo de Antonio Rius Facius, por ejemplo, conserva dos fotografias del corazón de Toral colgado de unos ganchos. Las espectaculares imágenes, que van 
acompañadas del siguiente texto: «Foto inédita del corazón perforado por una bala de J.L.T., instantes después de haber sido extraído por el doctor Aristeo Domínguez», ofrecen una puesta en escena del relato de la ciencia, del cuerpo ${ }^{13}$ y de la sangre, que deja a la vista precisamente los límites estéticos de la alegoría. Al igual que las chocantes tomas en las que se ven a soldados y a cristeros juntos, tras los acuerdos de paz, donde la víctima ya no existe ni siquiera como trofeo de caza; enmascarada y sepultada tras la charla y el ambiente distendido.

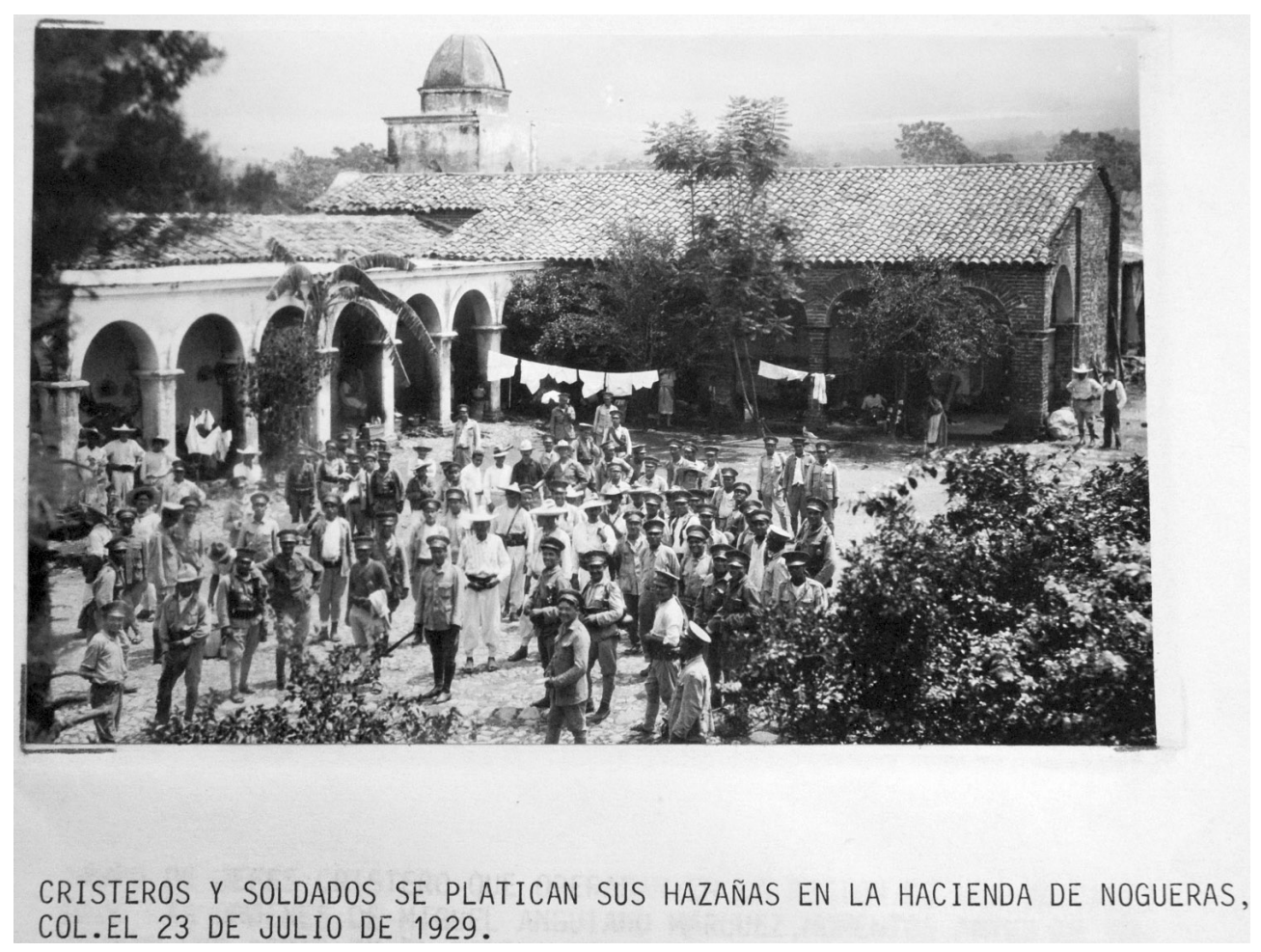

(C) Secretaria de la Defensa Nacional de México (SEDENA).

\section{Fotografía 4}

Cristeros y soldados tras los acuerdos de paz

13 De ese tercer cuerpo del que habla Valery al referirse al cuerpo interior, Consúltese: VALÉRY, Paul, «Reflexiones simples sobre el cuerpo» en Fragmentos para una Historia del cuerpo humano (Parte Segunda), Varios autores, Editado por Michel Feher con Ramona Naddaft y Nadia Tazi, Taurus, Madrid, 1991, p. 401. 


\section{Límites de la propaganda: Entre el exterminio y el martirio}

Las imágenes que han quedado de la Rebelión Cristera ofrecen inevitablemente rastros de la barbarie y la fatalidad, como se está viendo. «Mi pesadumbre — decía Barthes - pedía una imagen justa, una imagen que fuese al mismo tiempo justicia y justeza» (1982: 125). En otras ocasiones, sin embargo, "se trata precisamente de evitar a toda costa que las imágenes hablen ${ }^{14}$ (Kovacsics, 2007: 130). Por eso es necesario recordar y "para recordar hay que imaginar» (Didi-Huberman, 2004: 55).

Para Didi-Huberman, existen dos maneras de enfrentarse a las imágenes con contenido violento, que van a impedir atenderlas adecuadamente:

La primera consiste en hipertrofiarlas, en querer verlo todo en ellas. En resumen, en hacer de ellas unos iconos del horror (...) La otra manera consiste en reducir, en vaciar la imagen. En no ver en ella más que un documento del horror. (2004: 69-70)

Evidentemente, la propaganda de ambos bandos necesitaba enfrentarse de forma clara a esa especie de vaciado de contenido que se produce con las imágenes de las atrocidades de una guerra; para estabilizar en la opinión pública su propio discurso. Se trataba de instaurar una propaganda que se volcará cómodamente en las imágenes y, para ello, se llevaron a cabo unas estrategias firmes: el martirio de los cristeros frente al exterminio como propuesta gubernamental, que fueron estableciendo sus propios límites estéticos de representación de la víctima.

En líneas generales, se trataba de una propaganda que llevaba a cabo «la gestión de las actitudes colectivas mediante la manipulación de signos significativos» (Lasswell, 1927: 627), si bien el gobierno incluyó al cristero "como objeto de hostilidad» (Lasswell, 1927: 630). Mientras que los cristeros, a través de la Liga de Defensa Religiosa, además de la hostilidad contra el otro, atrajo a la masa de campesinos «deprimida y sin confianza en sí misma (...) por aquellos que parecen poseer el secreto de una dicha que le es esquiva, y que sacian su sed de heroísmo, por los «modelos», los iniciados, los poseedores del porvenir» (Domenach, 1968: 31).

Recontextualizando, la propaganda de la Liga apeló con el martirio, no solo a las creencias sino también a las emociones, donde la ideología «expresa un deseo, una esperanza o una nostalgia, más que la descripción de la realidad» (Althusser,

14 Kovacsics, pone como ejemplo, las fotografias que presentó Colin Powell el 5 de febrero de 2003 ante el Consejo de Seguridad de las Naciones Unidas, que supuestamente demostraban que Irak fabricaba armas de destrucción masiva. En su opinión, los títulos de las fotografias ya estaban puestos antes de hacer las tomas. 
1969: 234) y trató de borrar la contradicción entre sus ideas y sus actos, mostrando las imágenes de los mártires para enmascarar los límites de crueldad a los que estaban llegando también los cristeros: «En todos los casos, la ideología de la ideología (...) proporciona otras ideas correspondientes a los actos (aun perversos) que el sujeto realiza» ${ }^{15}$ (Althusser, 1988: 21).

La fotografia se hizo cargo de los fusilamientos, del tiro de gracia, del camino al paredón, de las decapitaciones, de los ahorcamientos, etc., para ofrecer así una dialéctica visual de la violencia, que fomentó el fanatismo para intentar tapar las altas dosis de sadismo y perversidad. No obstante, la víctima parece tan a la vista $\mathrm{y}$, sin embargo, se sitúa en un nivel de abstracción como consecuencia del cruce de propagandas; estableciendo una nueva realidad como lo entiende Stelzer: «La fotografia ha influido (...) creando estilos, incitando y transformando (...) Se ha sumado una nueva realidad, una tercera posición: la realidad fotográfica» (1981: 11). Una realidad fotográfica que utiliza el documento como espacio alegórico para "confrontarnos mejor a su ambigüedad por una parte, a su crueldad por otra» (Didi-Huberman, 2008: 183-4).

El horror que expresaban las fotografias, no solo fue un instrumento utilizado por los dos sectores; sino incluso la herramienta principal para la propaganda. De esta forma, las más lacerantes de cadáveres fueron aprovechadas sin pudor por el gobierno y la Liga. Obviamente, la confrontación de mensajes es estremecedora: unos ofrecían culpables y otros víctimas y cargaba, además, sobre todas las víctimas de la guerra el discurso de desintegración. En un contexto en el que «la convivencia entre estas dos cosmovisiones se mostraba entonces dificil, si no imposible, al alzarse cada una con la patente de exclusividad» (Ruiz, 2002: 13).

La actitud de los combatientes clarifica los límites estéticos de las fotografias más violentas y los mismos límites de la rebelión: «Así como el rebelde considera el asesinato como el límite al que, si llega, debe consagrarse muriendo, así también la violencia no puede ser sino un límite extremo" (Camus, 1996: 341). Los cristeros, por su parte, llevaron a cabo una transgresión desfigurada por el misticismo y, aparentemente, en su caso «la experiencia de la transgresión es una experiencia que mezcla el terror y el éxtasis» (Julius, 2002: 23); mientras que el gobierno realizó una censura "como forma de propaganda negativa» (Gubern, 1974: 297) al exhibir sus propios crímenes.

La propaganda sirve en este caso como motor de estetización y de exhibición de las fotografias de muertos, ejecuciones y similares, en las que el malo siempre es el otro: «El enemigo es el otro, que me pertenece, pues amenaza mi existencia» (Safranski, 2000: 130-1). Los límites a la hora de representar al otro, además, perfilan una disfunción dialéctica entre ética y estética: «Cómo la misma gente que comete

15 Conviene recordar que, para Althusser, los sacerdotes son profesionales de la ideología (ibídem). 
terribles actos de violencia contra sus enemigos puede desplegar una cálida humanidad y una sincera preocupación por los miembros de su propio grupo» (Zizek, 2009: 64) y será el propio documento fotográfico el que podrá dar las pistas.

No es de extrañar, por tanto, que Benjamin establezca un vínculo contundente entre estética, propaganda y política, ya que el documento debe obligadamente representar un papel importante en un contexto en el que la humanidad vive «su propia aniquilación como un goce estético de primer orden» (2003: 98-9) y porque necesariamente la víctima debe ser muestra de «su memoria más reprimida y de sus deseos más inarticulados» (Didi-Huberman, 2008: 151). Ahora bien, «la imagen se ve y eso es suficiente; y para verla basta poseer el sentido de la vista, basta con no ser ciegos» (Montero, 2006: 63), lo que por sí solo debería ser suficiente para descubrir quién es la víctima y cómo se construye.

Resulta obvio que hay que tomar con mucha precaución los argumentos en favor de desprestigiar a la fotografía como documento, ya que la imagen puede servir para evocar la violencia y a la víctima mostrada/ocultada; con lo cual se hace necesario estudiar "los criterios o las intenciones que se aplican a la manipulación» 16 (Fontcuberta, 1998: 154). En todo caso, es necesario establecer un marco crítico frente a la propaganda porque «todos los esfuerzos hacia una estetización de la política culminan en un punto. Este punto es la guerra» (Benjamin, 2003: 96).

Javier Ortiz Echagüe, en su estudio en torno a las fotografias del bombardeo de Gernika, coincide también en la necesidad de estudiar los mecanismos de la propaganda para enfrentarse al documento fotográfico: «La fe en la veracidad de la fotografia se convirtió en un arma de doble filo, capaz de facilitar la manipulación y el engaño. Las mismas imágenes podían servir para ilustrar distintos lugares o para justificar argumentos diversos, y en ocasiones abiertamente contradictorios» (2010: 58).

Bazin, por su lado, expresa ya con claridad el recorrido correcto: «Las virtualidades estéticas de la fotografia residen en su poder de revelarnos lo real» (1990: 29), o el propio Walter Benjamín, que afrontó el tema del crimen de forma directa: «¿No es la obligación del fotógrafo, descendiente del augur y del arúspice, descubrir en sus imágenes la culpa y señalar al culpable?» (2004: 52).

En el caso de la Rebelión Cristera, la utilización propagandística de las fotografias sirvió para poner en evidencia que «ambas partes contendientes adoptarán medidas extremas, con objeto de aniquilarse y desprestigiarse mutuamente» (Olivera, 1966: 183). En ese contexto, el martirio y el exterminio en su cruce han borrado

16 En opinión de Fontcuberta, el fotógrafo impregna la obra con su sensibilidad y con su ideología, aunque no cree que haya que reducir el documentalismo a una noción exclusivamente de estilo. 
también a la víctima a pesar de su supuesta visibilidad; pero las fotografias aportan claridad respecto a las responsabilidades políticas de cada bando. Por un lado, la Liga "conduciendo a la muchedumbre a la masacre» (Meyer, 2007: 118) y a la intervención en voladuras e incendios de trenes y, por otro, el gobierno con «incendios de ranchos y de pueblos, violaciones, matanzas, saqueo, (...) las brutalidades atribuidas al general Amaro son indescriptibles» (Meyer, 1973: 166-7).

\section{El retrato del mártir en las publicaciones de la Liga Nacional de Defensa Religiosa}

Todas las imágenes del conflicto, tanto las de muertos y fusilamientos, como las de la vida cotidiana en los campamentos militares, actos de las Asociación Católica de la Juventud Mexicana (ACJM), ataques de militares y agraristas contra cristeros o bienes eclesiásticos, los cristeros en fotos familiares, en los campamentos de guerra o de trabajo; sirvieron a los sectores católicos, en el contexto de la contienda, para crear y engrandecer la figura del mártir a través de la propaganda. Una propaganda, que se mostró muy eficaz ${ }^{17}$ : "Todas las cortapisas que el correo ponía para la circulación de esas fotografias, resultaron inútiles. Aun los mismos empleados, servían de correos» (Sodi de Pallares, 1936: 40).

La presencia de la fotografia era un hecho frecuente en los folletos, las hojas volantes, pequeñas revistas y en las tarjetas postales. En otras publicaciones, sin embargo, la utilización de la imagen fue menos importante, como el caso de la revista David y el periódico Peoresnada, cuyo «discurso admonitorio y represivo que aparece desde el primer número se mantiene hasta el último» (Olivera, Ruiz, 2005: 24). Así, por ejemplo, desde el principio queda claro que «si te dejas llevar de las pasiones (...) la maldición de Dios, de ese tu CRISTO REY, caerá sobre ti, sobre tu familia, y, si eres jefe, sobre tus soldados» (2005: 65). También en el periódico hacían públicos los triunfos de los coroneles cristeros: «Se da cuenta de las bajas que le han hecho al jefe callista J.B. Vargas, de las cuales dan prueba los cráneos de callistas que el río Huazamota descubrió» (2005: 32).

En síntesis, desde Peoresnada se va construyendo a través de esos mensajes disuasorios la imagen del defensor de Cristo Rey, del mártir y de sus límites de consolidación: «Ese enemigo ERES TÚ MISMO con tus no refrenadas pasiones» (2005: 65). Pero, la descripción de los cráneos que se hacen visibles en el río desbarata, de pronto, la imagen del mártir cristero; al tiempo que deja en el campo de lo visible imaginario las víctimas del otro bando «escamoteadas» desde el registro fotográ-

17 En alguna ocasión, se llegó a distribuir propaganda de forma masiva por la Ciudad de México, desde globos que sobrevolaron la metrópolis provocando una lluvia de octavillas. 
fico. En un intento por ofrecer consistencia a la figura del mártir; imposible de sustentarse, en este caso, desde las cenizas de la violencia; sino es a costa de utilizar un discurso estético «que permite que lo impresentable sea alegado tan solo como contenido ausente» ${ }^{18}$ (Lyotard, 1987: 25). Es decir, no apelar a los aspectos más violentos de esas fotografias sino es a través de una más que cuestionable sublimación, que lleva a la visualidad del sacrificio y a usurpar el discurso de la sangre.

Por otra parte, se publicaron numerosas hojas volantes ${ }^{19}$, que contenían fotografias de fusilamientos, retratos post mortem, destrozos en monumentos o bienes eclesiásticos, retratos de mártires cuando aún estaban con vida, entre otras. Fueron muy importantes porque se distribuyeron masivamente y circulaban de mano en mano y también porque, además de incluir imágenes de las muertes violentas de los cristeros, se apoyó en un lenguaje que incitaba a seguir en la lucha en tono trágico, heroico y folletinesco: "Sangre que clama», "Traicionados y sacrificados», etc. No todas las imágenes mantenían el mismo nivel de dramatismo y el texto, siempre eufórico, entusiasta y con altas dosis de victimismo, trataba de paliar esas carencias, cuando las había, y de mantener el nivel trágico que interesaba. A su manera, también la publicación de fotografias en estas hojas establecía cierta jerarquización en el grupo de los cristeros. De este modo, los miembros de la Liga o ACJM y los religiosos ocupaban portadas como los mártires de la guerra, dejando a los campesinos y a los grupos humildes de cristeros, un papel menos glorioso. De esta forma, la víctima era nuevamente enmascarada.

Una fotografia impactante, que se publicó en estas hojas, fue la del cura Sedano, colgado de un árbol, que deja a la vista una escena de gran patetismo, sobre todo porque se ha elegido una toma lateral que realza la postura del ahorcamiento; al verse claramente la rigidez de la soga. En las piernas del muerto hay un cartel en el que está escrito el siguiente texto: "Éste es el cura Sedano» para reafirmar a la víctima, evidenciar la violencia y llamar a la acción. Debajo de la fotografia otra sentencia que censura la actitud de los callistas: «El cadáver del P. Sedano expuesto al público por los soldados del presidente Calles». La fotografia del padre Sedano evidencia cómo el relato siniestro se enfrenta a la estetización adherida al martirio;

18 Para Lyotard, en estos casos, se continuaría ofreciendo al contemplador un consuelo y un placer. Sin embargo, «estos sentimientos no forman el auténtico sentimiento sublime, que es una combinación intrínseca de placer y de pena» (Lyotard, 1987: 25).

19 El Archivo cristero de Aurelio Acevedo de la UNAM (Universidad Nacional Autónoma de México) recoge la colección pública más importante compuesta por treinta y siete folletos de la Liga, tamaño tarjeta postal en color amarillo pálido, cuyo diseño estandarizado consiste en su parte delantera de una fotografia más o menos grande y un texto breve y, por la trasera, un escrito amplio en el que solían mezclarse un discurso de crítica y/o exaltación de las virtudes del muerto, con un enardecimiento de la doctrina cristiana. La compilación se presenta, al cabo de los años, como un auténtico botón de muestra de la utilización de la fotografia en las hojas volantes. 
como consecuencia del mensaje partidista. Otra forma de estetizar la violencia, era publicando la última fotografia que se le había hecho con vida: años, meses o incluso minutos antes de morir y, cuando era así, se hacía constar precisamente con la frase: «El último retrato» ${ }^{20}$. Sin embargo, en todos los casos, el martirio como destino heroico coloca a la víctima en un nivel alegórico; lo que conlleva nuevamente una dialéctica de los límites estéticos y propagandísticos. En conclusión, todas las fotografias dejaban a la vista que la violencia era incluso deseada para llegar a ser mártir.

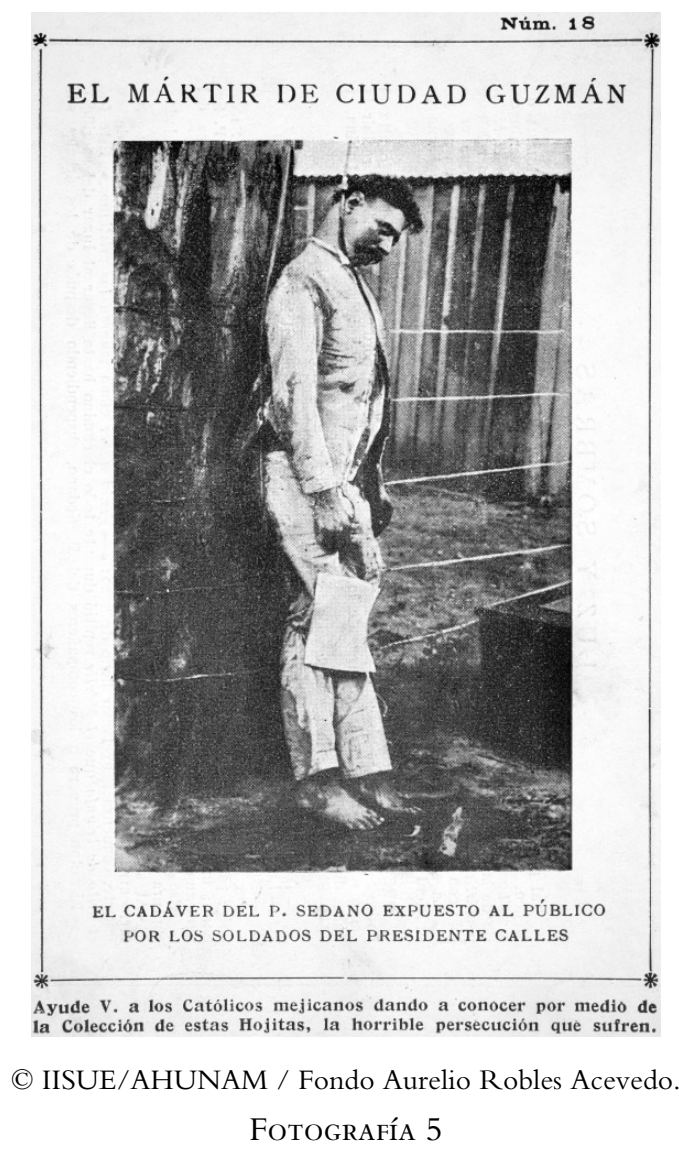

El cura Sedano tras ser ahorcado

20 En concreto en el caso de León Toral, al día siguiente de su ejecución los periódicos de mayor tirada no publicaron fotografias de su ejecución, aunque El Universal Gráfico incluyó una del acusado con los militares camino al paredón con el texto: «El último retrato». Curiosamente, en 1967, ese mismo periódico publicó dos fotografias con el titular: «Así murió Toral». Una de la ejecución y la otra del estado actual del sitio donde le ejecutaron, en esta última una persona señala las huellas de las balas en la pared y de los sacos que colocaron para su fusilamiento y que están sugeridos por una tonalidad distinta de la pared. 
En lo que respecta a los folletos, se prestará atención al de Ave María, concretamente el número que lleva por título: ¿Hay persecución contra la Iglesia en México?, que incluye numerosas fotografias a toda página. Ezequiel Roca señala en el prólogo del folleto lo siguiente: «¿Cómo se han obtenido estas fotografias? Cosa increíble; sus mismos perseguidores las han mandado sacar. Durante el asesinato del P. Pro y compañeros funcionaban continuamente, por lo menos, tres máquinas fotográficas» (Roca, 1928: 3).

La primera fotografia de la revista, muestra a soldados callistas, disfrazados de religiosos y portando estandartes e ídolos cristianos, que hacen amagos de disparar sobre los muertos y escenifican una burla inquietante, ante la presencia de los cadáveres. La imagen contiene el siguiente texto en su interior: «Objetos que les fueron recogidos a los fanáticos asaltantes del tren directo que encabezados por los frailes bandidos Ángel Vera y Vizcarra fueron completamente dispersados por las fuerzas del gobierno, en sus últimos reductos del cerro Gordo. Ocotlan, J. 5-3-27» ${ }^{21}$.

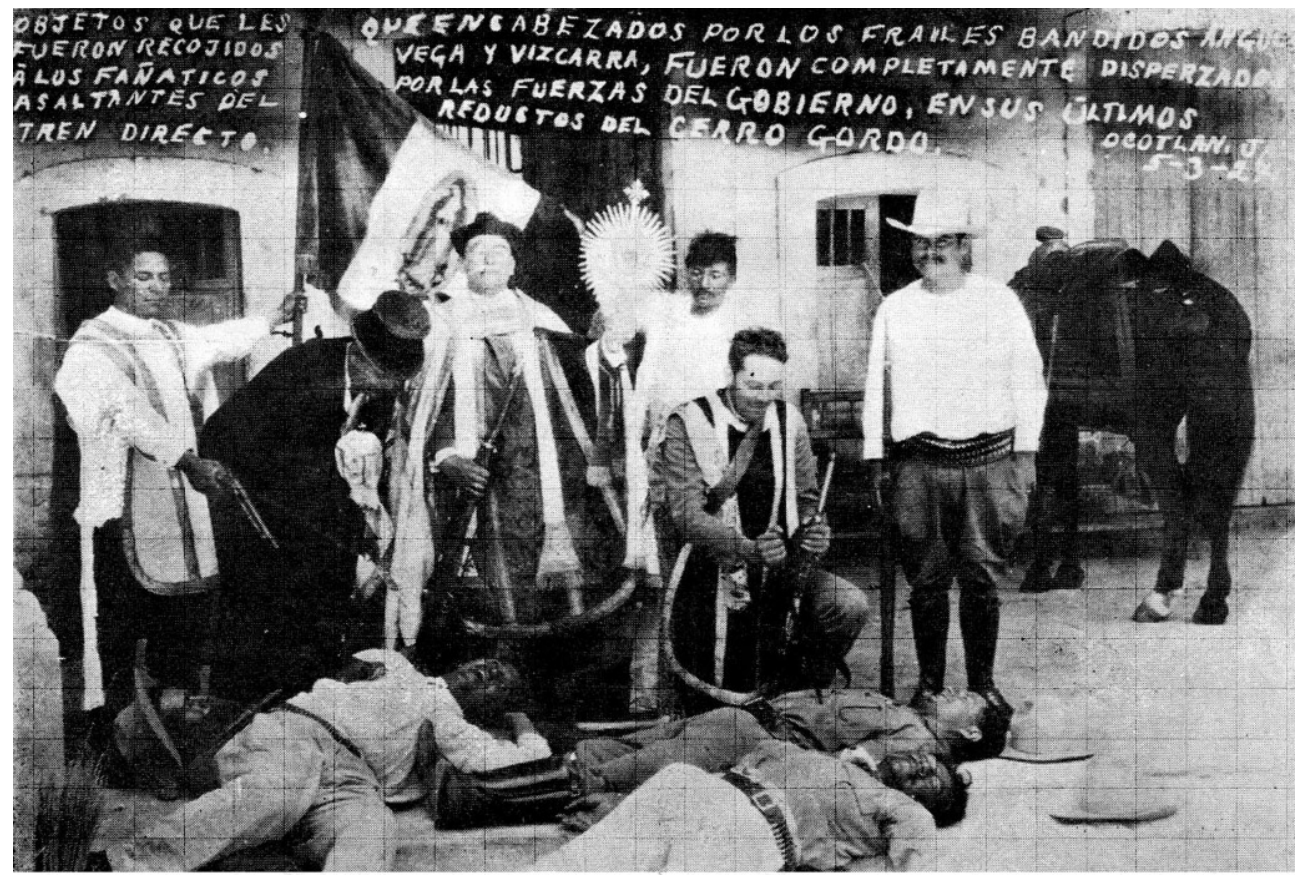

Los soldados y empleados de Calles revestidos con los ornamentos sagrados. (La fotografía está sacada y anotada por los mismos militares).

(C) IISUE/AHUNAM / Fondo Aurelio Robles Acevedo.

FOTOGRAFÍA 6

Sátira propagandística ante cadáveres de cristeros

21 Texto escrito por militares sobre la propia fotografia. 
De tal forma que, gracias a los textos, nos enteramos de que la fotografia escenifica una venganza. El pie de foto, por su parte, incluye las siguiente palabras: «Los soldados y empleados de Calles revestidos con los ornamentos sagrados (la fotografía está sacada y anotada por los mismos militares)» ${ }^{22}$. La pose fotográfica de algunos de estos militares contrasta con los movimientos teatrales de acción de la otra parte, que permanece actuando a modo de juego con los fusiles, etc. El hecho de que esta fotografia sea la primera del boletín resulta interesante porque recoge las mutuas acusaciones de perversidad. No obstante, la parodia favorece al simulacro del mártir.

La imagen de la junta vecinal ahorcada en Nayarit aparece, en este boletín, publicada al lado del siguiente aviso: «Serán pasados irremisiblemente por las armas» todas aquellas personas que ayuden a los rebeldes, así como todas aquellas que soliciten algún sacramento, etc.» ${ }^{23}$. Al lado de este anuncio, la imagen de los ahorcados se presenta como la puesta en evidencia de que, efectivamente, se están cumpliendo las amenazas. Los miembros de esta junta vecinal aparecen todos colgados del mismo árbol, creando una imagen casi fantasmagórica de un escenario de violencia, radicalidad y fanatismo. El tema del ahorcamiento se completa en este boletín con la de los cristeros ahorcados en los postes de telégrafo de las vías del $\operatorname{tren}^{24}$ y la del cura Sedano. Los ahorcamientos en los postes de las líneas férreas representaban una respuesta a los ataques de los cristeros contra trenes. La violencia en off, en rememoración de un atentado, y la violencia en on, con estos ahorcados, chocan inevitablemente en la fotografia; por lo que se tambalea la imagen del mártir.

La publicación de todos estos documentos visuales de atropellos cometidos contra los cristeros, también tenía, como se está viendo, una sorprendente función meta fotográfica, al condenar la utilización perversa de la imagen por parte de los gobernantes, como lo demuestran algunos de los textos de los pies de foto, incluidos en esta publicación: «La fotografía está sacada y anotada por los mismos militares», «La fotografía se tomó mientras sus cuerpos fueron expuestos en el Palacio Municipal», y «La fotografía la mandó sacar el jefe encargado de la ejecución», entre otros. De esta forma, las fotografias del conflicto pasaban a ser una parte importante de la confrontación y una forma de relacionar la atrocidad exclusivamente con el enemigo; al mismo tiempo que se dejaba de lado el escenario real de destrucción, en un juego de desplazamientos retóricos, para estabilizar el sacrificio.

22 Se trata del pie de foto de esa misma fotografia, anotado por los cristeros.

23 En este caso, está escrito por los cristeros para poner en evidencia a los militares.

24 En concreto, y en época más reciente, la fotografía de los ahorcados en las vías del tren fue uno de los motivos incluidos en la falda de miss México 2007 para el concurso de miss universo. Finalmente tuvo que ser rediseñada, ante las protestas generalizadas. 


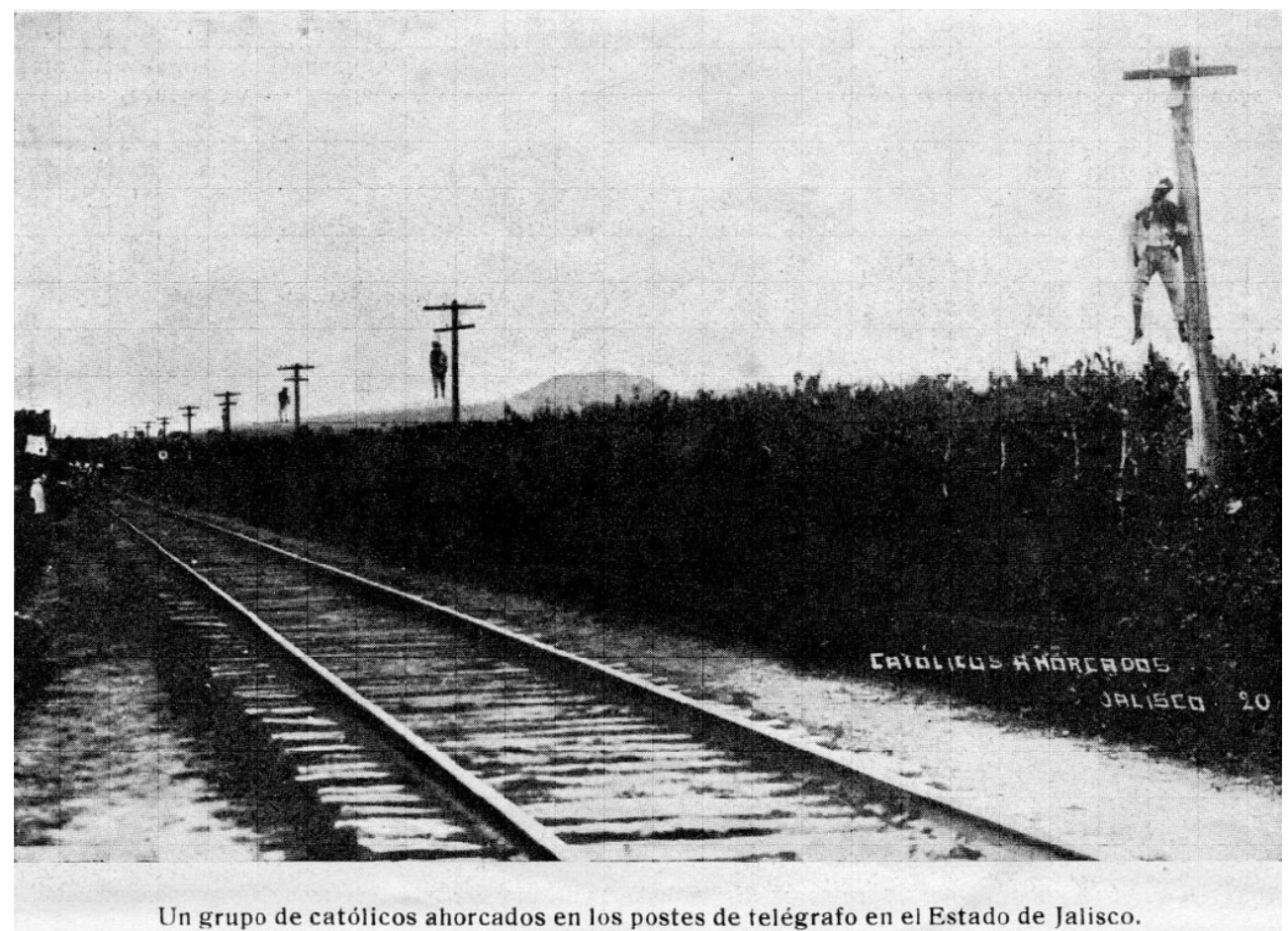

(C) Revista Ave María.

\section{Fotografía 7}

Cristeros ahorcados

Los textos que se adjuntaron a las fotografias en esta publicación sirven, además, de refuerzo para enfatizar las acciones de los enemigos: «Se dice que a Valencia Gallardo le cortaron la lengua por invocar a Dios» «Anacleto González Flores (...) fue atormentado y por fin asesinado (...). La esposa y sus dos hijitos contemplando el cadáver mutilado de su padre», etc. Otras veces, el texto trataba de frenar la contundencia de la imagen. Por ejemplo, en la de la destrucción del monumento a Cristo Rey; impresa en hojas volantes. En ese caso, las palabras y los recursos gráficos tratan de amortiguar el efecto emocional en el espectador, al tiempo que denuncian el derrumbamiento del ídolo.

Barthes definió en su momento con claridad la relación "parasitaria» entre texto e imagen: «Es la palabra la que aparece para sublimar, hacer más patética o racionalizar la imagen (...) ahora el texto le añade peso a la imagen, la grava con una cultura, una moral, una imaginación» (Barthes, 1986: 22). En definitiva, son textos que viven de la imagen y que «no son apenas disociables de esa puesta en escena de un ri- 
tual que determina a la vez para los sujetos que hablan las propiedades singulares y los papeles convencionales» (Foucault, 1970: 24).

Frente a la exhibición de los cadáveres por parte del gobierno, la Liga respondía con la ostentación de estas imágenes, a modo de prueba y de denuncia de los actos perversos del enemigo y, también, para ofrecer consistencia a la figura del mártir; creada y sustentada desde las cenizas de la violencia como objeto de exhibición; en un intento por favorecer la identificación. También aquí Barhes aporta una clave fundamental cuando clarifica que, en ocasiones, la connotación tiene una función reguladora y que "preserva el juego irracional de la proyección-identificación» (1986: 23), aunque "cuanto más directo es el trauma, más difícil resulta la connotación; más aún: el efecto «mitológico» de una fotografia es inversamente proporcional a su efecto traumático» (1986: 26). Lo que explicaría que los textos que acompañan a muchas fotografias de la Cristiada parezcan fruto de una performance hiperbólica o exagerada, aunque los hechos paradójicamente sí sean excesivos y la morbosidad y perversidad se trate de asumir bajo el dominio estético de la estrategia propagandística. Además, hay que tener en cuenta que «la capacidad de la fotografia para borrar la memoria ha sido contrarrestada por su transformación (...) de solo una imagen inscrita en el pasado a un cambio que nos afecta emocionalmente de cerca» (Batchen, 2007: 24). Se trata, en opinión de Batchen de un proceso en el que las fotografias se convierten en fetiches, que sirven para el culto al recuerdo. En este caso, se podría decir del culto a la violencia como metáfora de la víctima.

\section{La muerte del mártir: el fusilamiento de los hermanos Pro, Vilchis y Tirado}

Un ejemplo de escenificación del cruce radical de estrategias fue el caso del fusilamiento del padre Miguel Agustín Pro, su hermano Humberto Pro ${ }^{25}$, Luis Segura Vilchis y Juan Antonio Tirado Arias, que fueron ejecutados el 23 de noviembre de 1927 por su presunta implicación en el atentado fallido contra Álvaro Obregón. La muerte de los acusados sin juicio previo levantó las protestas de la opinión pública. El despliegue de fotografias de la ejecución sorprende hasta hoy en día:

${ }^{25}$ Humberto Pro presuntamente prestó su coche para cometer el atentado fallido, aunque no se sabe si estuvo implicado directamente. Al padre Miguel Agustín Pro se le condenó sin haber probado que él supiera nada del préstamo del coche que hizo su hermano o del atentado. Segura Vilchis y Tirado Arias, sin embargo, parece ser que sí participaron de forma directa en el intento de asesinato. Los pormenores de este caso pueden leerse en: DRAGÓN, Antonio, Vida íntima del Padre Pro, S.J. Editorial: Obra nacional de la buena prensa, A.C., México, 2007. 
Las fotografias más demandadas y reproducidas fueron las que forman una serie completa — paso a paso y desde diferentes ángulos— de los fusilamientos $(\ldots)$ dan a conocer a la opinión pública cuál es el fin de quienes obran en contra de los símbolos del gobierno establecido. Pero fueron también reproducidas para comprobar la infamia, cometida por Calles. (Palacios, 2002: 2)

La secuencia de imágenes de los fusilamientos está compuesta, en términos generales, por fotografias en las que puede verse a los inculpados dirigirse al paredón, momentos antes de la descarga, durante los disparos, mientras les dan los tiros de gracia y, por último ya, sus cadáveres en las posiciones en las que se han desplomado. La figura de padre Pro parece centrar en su persona toda la tragedia, al mostrar el doble camino de consolidación para el mártir: la muerte y la propaganda. Las fotografias que le muestran sentado de rodillas rezando y de pie, con los brazos en cruz esperando la descarga, ayudan a consolidar la imagen del mártir; al escenificar de modo tan contundente la figura del verdugo. También los retratos post mortem rememoran el martirio y su finalidad.

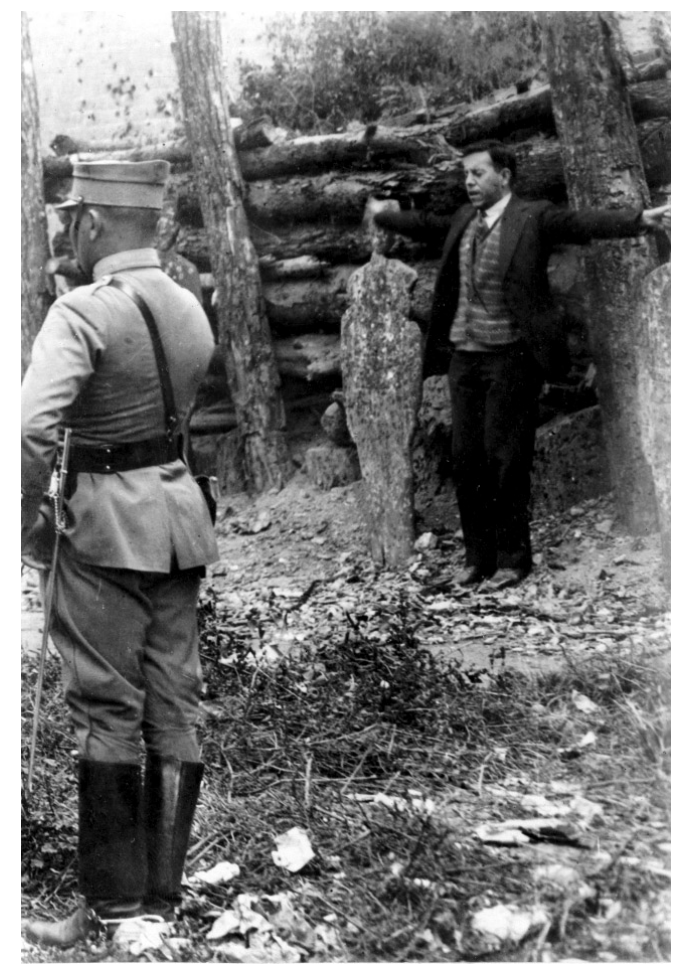

(C) Archivo del Arzobispado de México.

Fotografía 8

El padre Pro con los brazos en cruz antes de ser fusilado 


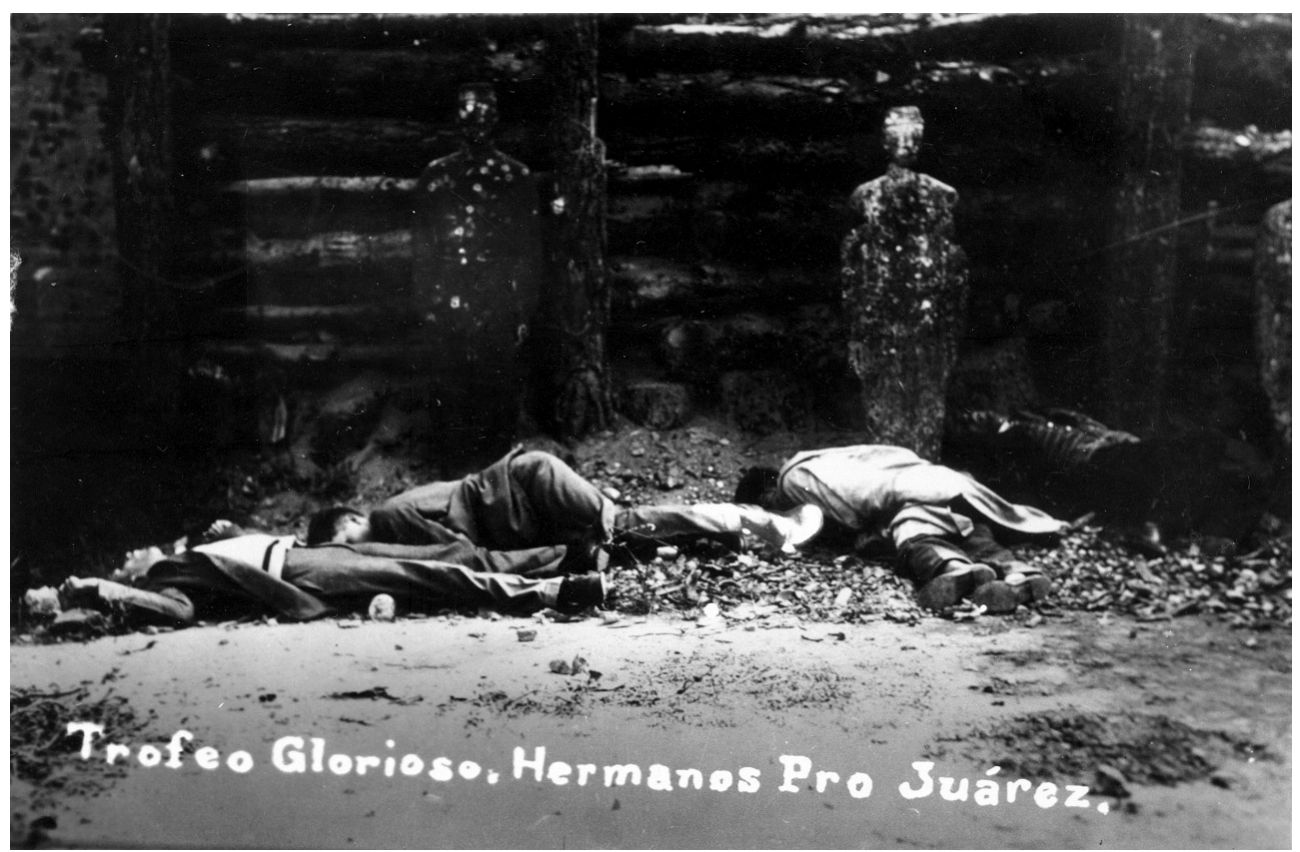

(C) Archivo del Arzobispado de México.

Fotografía 9

Agrupamiento de cadáveres tras la ejecución

El camino del martirio y el del exterminio están simbolizados en esta secuencia fotográfica, en la que las víctimas ejecutadas son botines a exhibir, además de un "Trofeo Glorioso». Las instantáneas de la muerte se apegan con tal contundencia al contexto histórico, que sus rasgos estéticos están muy vinculados con el castigo; que se está fotografiando al mismo tiempo que está teniendo lugar. El camino al paredón, por su lado, no es otro que el sendero hacia la destrucción y hacia el sacrificio. El contraste entre el cuerpo vivo caminando, chocará después —estéticamentecon el cuerpo muerto tras la descarga.

También en esta misma serie, hay que destacar las fotografias de los tiros de gracia, que son la otra cara del camino al paredón; en realidad, representan el principio y el fin de la historia de cada uno de los fusilamientos, que comienzan en esa fría mañana con el pausado caminar de los prisioneros y termina con el ruido de la metralla sobre los cuerpos muertos, derrumbados en el suelo. El remate efectuado a los reos, no solo certifica de forma más clara la muerte de los acusados, sino que ratifica, también desde lo visible, la sentencia de muerte. La cámara, en estos casos, debe acercarse lo más posible a los cadáveres. El tiro de gracia termina definitivamente 
con cualquier esperanza de vida para los acusados, pero no supone en ningún momento el punto final para la serie fotográfica; que continúa con la captación de las imágenes del agrupamiento de cadáveres en el suelo y sucesivos retratos post mortem.

El periódico Excelsior, el que más fiel era a la ideología gubernamental, publicó seis fotografias de la ejecución con el siguiente titular: «Cuatro personas fueron ejecutadas ayer por el atentado contra el Gral. Obregón». Sin embargo y, a pesar de que el reportaje parece muy completo, se nota la ausencia de la toma del fusilamiento del padre Pro. En el conjunto de la secuencia, el escarmiento se pone en escena con el desplome de los cuerpos y el derrumbe del mártir ante la presencia del pelotón de fusilamiento y de las autoridades. El disparo, el derrumbamiento, el rezo, el camino al patíbulo, la entereza y la rigidez gubernamental, se definen como los elementos de apoyo para la aniquilación del mártir. El Excelsior evitó publicar la imagen del padre Pro con los brazos en cruz en el momento mismo del fusilamiento, probablemente por temor a que se pudiera producir una fuga del discurso propagandístico y provocar una exaltación del mártir en lugar de su desintegración.

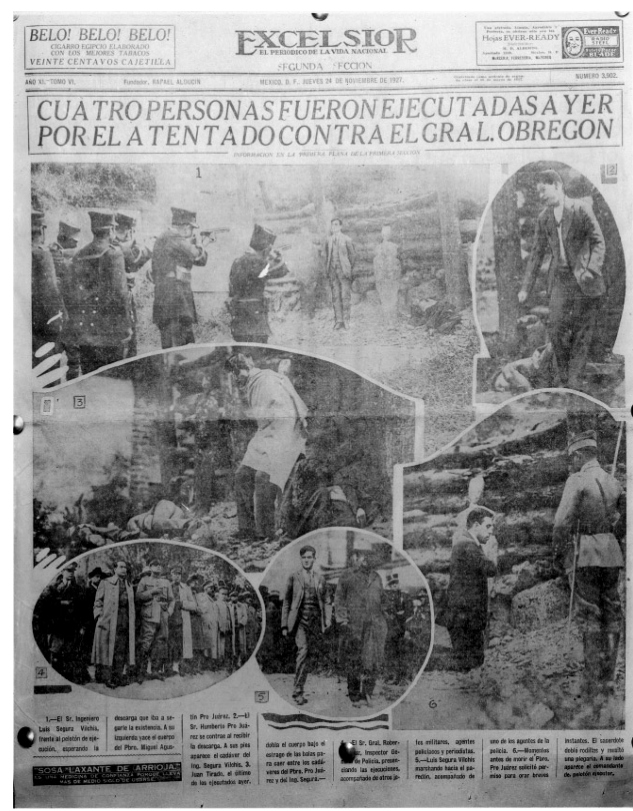

(C) Archivo del Arzobispado de México.

Fotografía 10

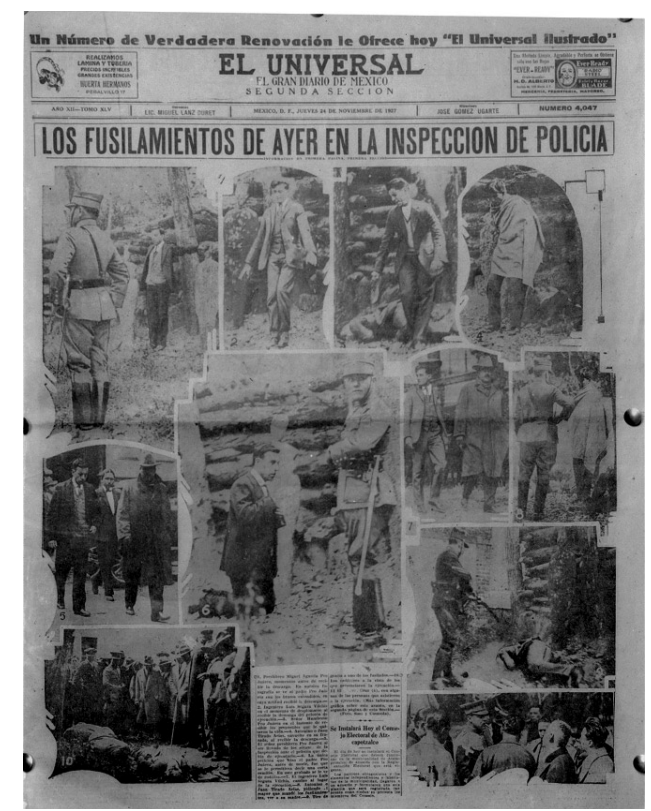

(C) Archivo del Arzobispado de México.

FOTOGRAFía 11

El Universal, por su parte, incluyó en portada once imágenes de las ejecuciones que ocupaban la práctica totalidad de la página. La publicación de la fotografia del tiro de gracia sobre uno de los ejecutados y la del grupo de cadáveres de los reos, ro- 
deados del público; otorgan a esta secuencia una imagen de violencia extra y mayor voyerismo, si se compara con la del Excelsior. Las fotografias van acompañadas del titular: «Los fusilamientos de ayer en la inspección de policía». La muerte de los acusados, desde este reportaje, en el que sí se incluye el fusilamiento del padre Pro, constituye la metáfora de la muerte del mártir y la paradoja de su deseada resurrección. Es precisamente, la performance real de la tragedia del padre Pro, lo que permitió a la propaganda cristera, imprimir en la opinión pública una identificación fuerte entre el padre Pro, la guerra, el cristero y el martirio como meta.

Lo que prueba que el choque de estrategias propagandísticas fue brutal, en tanto en cuanto los hechos también lo eran. No obstante, los últimos momentos del padre Pro configuran el límite estético de representación del mártir con esos brazos en cruz, anulando la abyección en favor de los símbolos:

Por último, me parece que el cuadro del último minuto de la vida del padre Pro, ha representado claramente a los dos órdenes enfrentados durante el conflicto religioso (...) ambos órdenes se encuentran presentes en el mismo sitio de la muerte aunque, el escenario, había sido preparado desde hacía mucho por el imaginario histórico. (Espinosa, 2006: 1)

Está en juego, por tanto, no solo el camino que va de la memoria colectiva hasta la creación de imágenes-iconos, sino también el verdadero exterminio de la víctima, que se produce en un contexto de estetización de la violencia a través del martirio, al convertirse en una imagen de devoción, sagrada: «El paso que va de la meditación consciente sobre una imagen sagrada a las visiones místicas que aparentemente se producen por sí solas, no es demasiado grande» (Burke, 2001: 66-8). Únicamente el padre Pro con los brazos en cruz intenta paralizar el exterminio del mártir, al apropiarse de la imagen del padecimiento ${ }^{26}$ en sus últimos momentos de vida. El Universal no consiguió poner freno en estas fotografias a la feroz lucha de propagandas que se escenificó con los fusilamientos y durante todo el conflicto; en el que el exterminio del otro colocaba a la víctima en un escenario de ficción y de puesta en escena permanente; mostrando la metáfora de su propia aniquilación.

26 Según la versión ofrecida por Daily Mirror, el padre Pro — con los brazos en cruz mientras esperaba la descarga - pidió el perdón para sus verdugos: «May god have mercy on you all». El periódico neoyorkino publicó en portada tres fotografias sobre los fusilamientos, pero todas eran del padre Pro. El Daily News, por su parte, destacó visualmente el castigo sobre Segura Vilchis, el más sospechoso de todos los implicados. 


\section{Conclusiones}

La Rebelión Cristera ${ }^{27}$ es un acontecimiento prácticamente tabú en México incluso hoy en día, lo que da idea del contexto que envuelve a cualquier estudio sobre el tema. La investigación ha puesto en evidencia que los documentos fotográficos que han quedado del conflicto en los archivos estudiados, arrojan una conclusión contundente, en el sentido de que la censura ha provocado que la mayoría de las imágenes sean de los cristeros. El gobierno no quiso en ningún momento dar la sensación de debilidad y no le interesó difundir fotografias de sus bajas. Los cristeros, por el contrario, buscaron insistentemente demostrar que estaban siendo exterminados por el ejército mexicano. De tal forma que a los dos bandos combatientes les servían las mismas instantáneas de cristeros muertos para hacer propaganda. Y también se ha podido constatar que la fotografia se convirtió en un elemento estratégico en la guerra, como ya había sucedido con la Revolución Mexicana.

En primer lugar, para centrar la investigación de estos documentos fotográficos de los fondos y publicaciones analizadas, ha sido necesario establecer los límites estéticos de representación, en el cruce con las dos estrategias propagandísticas llevadas a cabo: el martirio como meta final para los cristeros y el exterminio del alzado (cristero) que propugnó el gobierno de Calles. Entre esos límites destacan la necesidad de dirigir la lectura de las imágenes de violencia desde la propaganda, el ocultamiento de las víctimas no cristeras, las dificultades ideológicas a la hora de consolidar al mártir y el discurso estético de la muerte y de lo abyecto.

Respecto a las estrategias propagandísticas, el choque de mensajes fue radical para unas fotografias igualmente extremas, que ofrecían víctimas y culpables simultáneamente. No obstante, la estetización de la violencia fue utilizada por los intelectuales cristeros de la Liga Nacional de Defensa Religiosa para la consolidación de la figura del mártir; lo que no impidió que difundieran las imágenes más violentas de sus bajas. El resultado final del cruce de propagandas es la negación de todas las víctimas, ya que se han convertido en metáforas de la violencia o han entrado en una escalada de metáforas que provoca su alarmante desintegración; no solo desde el registro fotográfico sino instalándose en el imaginario como un hueco vacío y una quiebra en el relato visual e histórico.

Por otro lado, a pesar del control gubernamental de los periódicos de mayor tirada, la Liga publicó durante la guerra panfletos, hojas volantes, la Revista Ave Ma-

27 Ocurrida inmediatamente después de la Revolución Mexicana, al producirse un enfrentamiento entre la Iglesia y el Estado, que se llevaba escenificando desde la constitución de 1857 y la encíclica Rerum Novarum del Papa León XIII en 1891. El intento de Plutarco Elías de establecer un gobierno laico al poner en práctica el artículo 130 de la Constitución de 1917, fue mal recibido por los sectores católicos. 
ría y el periódico Peoresnada, entre otros, en los que trató de construir la imagen del mártir religioso sobre el discurso de la violencia. En estas publicaciones utilizaron las fotografias para adoctrinar a las bases cristeras y mostrar a través de los documentos más violentos la perversidad del enemigo.

Por último, el fusilamiento de los hermanos Pro, Vilchis y Tirado ha permitido dar un ejemplo concreto de estudio del cruce de propagandas y de la forma en que los límites estéticos planteados se ponen en juego desde lo fotográfico, para extenderse a la opinión pública e instalarse después en el imaginario. En este caso, la estetización del martirio en la figura del padre Pro instruye sobre la inmolación de la víctima y de su metáfora.

\section{Referencias bibliográficas}

Althusser, Louis (1969) For Marx. Londres: Verso Books.

Althusser, Louis (1988) Ideología y aparatos ideológicos del Estado. Freud y Lacan. Buenos Aires: Nueva Visión.

Barthes, Roland (1982) La cámara lúcida. Nota sobre la fotografia. Barcelona: Editorial Gustavo Gili.

Barthes, Roland (1986) Lo obvio y lo obtuso. Imágenes, gestos, voces. Barcelona: Editorial Paidós.

Batchen, Geoffrey (2007) ¿Qué ha sido de la fotografia? Barcelona: Editorial Gustavo Gili.

Bazin, André (1998) Ontología de la imagen fotográfica. Madrid: Editorial Rialp.

Benjamín, Walter (2003) La obra de arte en la época de su reproductibilidad técnica. México: Editorial Itaca.

Benjamín, Walter (2004) Sobre la fotografía. Valencia: Edición Pre-Textos.

Bruckner, Pascal (1996) La tentación de la inocencia. Barcelona: Editorial Anagrama.

Burke, Peter (2001) Visto y no visto (el uso de la imagen como documento histórico). Barcelona: Editorial Crítica.

Camus, Albert (1996) El hombre rebelde. Madrid: Alianza Editorial.

Didi-Huberman, Georges (2008) Cuando las imágenes toman posición: el ojo de la historia. Madrid: Machado libros.

- (2004) Imágenes pese a todo. Memoria visual del holocausto. Barcelona: Paidós Ibérica.

Domenach, Jean-Marie (1968) La propaganda política. Buenos Aires: Editorial Universitaria.

Durand, Régis (1990) Le regard pensif. Lieux et objets de la photographie. París: La Différence.

Eliade, Mircea (1992) El mito del eterno retorno. Madrid: Alianza Editorial. 
Espinosa Díaz, Luis Humberto (2006) Pro, imagen que pudo rasgar al tiempo. Centro de Estudios Cristeros. Anacleto González Flores. Disponible en: http://www.uag.mx.

Fontcuberta, Joan (1998) El beso de Judas. Barcelona: Gustavo Gili.

Foucault, Michel (1974) El orden del discurso. Buenos Aires: Tusquets Editores.

Gubern, Roman (1974) La imagen y la cultura de masas. Barcelona: Editorial Bruguera.

Julius, Anthony (2002) Transgresiones. El arte como provocación. Barcelona: Ediciones Destino.

Kovacsics, Adan. (2007) Guerra y lenguaje. Barcelona: Editorial Acantilado.

Lasswell, Harold D. (1927) The Theory ol Political Propaganda. The American Political Science Review, 21 (3), 627-631.

Lyotard, Jean-Francois (1987) La postmodernidad explicada a los niños. Barcelona: Editorial Gedisa.

Marzabal Albaina, Íñigo (2007) Cine, ética y medicina ante el final de la vida: El poder de las metáforas. Revista de Medicina y Cine, 3 (1). Disponible en: http://revistas.usal.es/ index.php/medicina_y_cine/article/view/239/446

Meyer, Jean (1973) La Cristiada. México: Siglo XXI Editores. Tres volúmenes.

-2007) La Cristiada (en imágenes). México: Editorial Clio.

Montero Lozano, Francisco X. (2006) Los mercenarios de la imagen: mercadotecnia versus democracia. México: Siglo XXI.

Olivera, Alicia (1966) Aspectos del conflicto religioso de 1926 a 1929. México: Instituto Nacional de Antropología e Historia.

Olivera, Alicia y Ruiz Naufal, Víctor Manuel (2005) Peoresnada, periódico cristero. México Distrito Federal: Instituto Nacional de Antropología e Historia.

Ortiz Echagüe, J. (2010) «Esto no es Guernica...». Fotografía y propaganda de la destrucción de Gernika en la prensa durante la Guerra Civil Española. ZER Revista de Estudios de Comunicación, 15 (28), 151-168.

Palacios Suárez, Guillermina (2002) Foto Cristera al servicio de la guerra. Cuartoscuro. Agencia de Fotografía y Editora, n. ${ }^{\circ}$ 52, Ene-Feb, 2002. Disponible en: http://cuartoscuro. com

Roca, Ezequiel (1928) ¿Hay persecución contra la Iglesia en México? Revista Ave María. Barcelona.

Ruiz Sánchez, José Leonardo (2002) Prensa y propaganda católica (1832-1965). Sevilla: Universidad de Sevilla.

Safranski, Rüdriger (2000) EL MAL o el drama de la libertad. Barcelona: Tusquets Editores.

Sodi de Pallares, María Elena (1936) Los cristeros y José de León Toral. México: Editorial Cultura.

Sontag, Susan (2003) Ante el dolor de los demás. Madrid: Santillana Ediciones.

Stelzer, Otto (1981) Arte y fotografia: contactos, influencias y efectos. Barcelona: Gustavo Gili. 
Taylor, John (2006) Body Horror. Photojournalism, catastrophe and war. Manchester: Manchester University Press.

Zizek, Slavoj (2009) Seis reflexiones marginales. Buenos Aires: Paidós.

\section{Archivos fotográficos investigados en Ciudad de México}

Archivo Histórico de la Secretaría de la Defensa Nacional (SEDENA). Álbum fotográfico del fondo cristero.

Archivo Histórico de la Arquidiócesis de México. Fondo Cabildo. Sección Catedral.

Archivo de Aurelio Acevedo de la Universidad Nacional Autónoma de México (UNAM).

Fondo fotográfico cristero CEHM-CARSO. Colección Antonio Rius Facius. Archivo Casasola. Acervo de la Rebelión Cristera.

Archivo Fideicomiso Plutarco Elías Calles. Fondo Joaquín Amaro y Fondo Fernando Torreblanca.

Archivo General de la Nación (AGN). Fondos: Enrique Díaz, Hermanos Mayo y Sección Presidentes.

Fondos del Instituto Nacional de Antropología e Historia: Fotografias de expedientes, Colección Alfredo Hernández Quesada, compuesto de las colecciones: Heriberto Navarrete, Jesús Padilla, Efrán Quezada y Luis Rivera Del Val.

\section{Publicaciones}

Diario Excelsior. Periódico El Universal. Universal gráfico.

Revista Ave María. Periódico Peoresnada.

Colección de hojas volantes del fondo de Aurelio Acevedo.

Material de propaganda religiosa de la Liga Defensora de las Libertades Religiosas. Archivos de Palomar y Vizcarra. 